\title{
PRESERVING HISTORIC BEARING STRUCTURES BY PRUDENT INTEGRATION IN NEW STRUCTURES
}

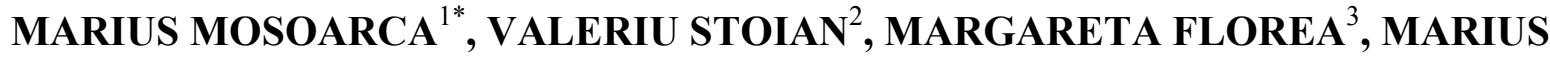 NICULESCU ${ }^{3}$ AND MARIUS PALADE ${ }^{3}$}

\author{
${ }^{1}$ H.I. STRUCT SRL \\ Ciocarliei Street, nr 86, 300600, Timisoara, Romania \\ e-mail: mmosoarca@histruct.ro, web page: http://www. histruct.ro (*corresponding author) \\ ${ }^{2}$ Faculty of Civil Engineering, Politehnica University of Timișoara (UPT) \\ Traian Lalescu street, nr. 2, 300223, Timisoara, Romania \\ e-mail: valeriu.stoian@upt.ro \\ ${ }^{3}$ H.I. STRUCT SRL \\ Ciocarliei Street, nr 86, 300600, Timisoara, Romania \\ e-mail: office@histruct.ro, web page: http://www. histruct.ro
}

Keywords: Historical Structure, Preservation, Re-use, Consolidation

\begin{abstract}
For the effective consolidation of damaged historic load-bearing structures, it is necessary for the designer to understand the causes of the damage but also to know and apply the most effective consolidation methods, in order not to affect the cultural value of the building. The problem becomes even more complex for the designer when it is desired only to keep a damaged area of a historic building, which was part of an aggregate of historic buildings. Keeping this area is needed because buildings have been seismically interacting over the past 150 years, and it is necessary to maintain the static equilibrium of the building aggregate.
\end{abstract}

In most cases, in order to safeguard a damaged historic building, is achieved by consolidating the structural elements composing the building, resulting in extensive consolidation areas, long construction periods and expensive and hard to implement solutions. Additionally, it is challenging to predict the response of the building over time to various actions without continuous monitoring, which is difficult to achieve, because of the disturbance on building occupants.

The paper presents an alternative solution of safeguarding interventions on a historic building, damaged by settlement and earthquakes, through its prudent connection to the load-bearing structure of a new building. The building is located in the St. Gheorghe Square in Timisoara, Romania, located in the Banat seismic area with a peak ground acceleration of 0,20g [1]. This alternative solution saves the historic building from the total demolition, has the advantage of minimal consolidation interventions, but also preserves the historical balance between the buildings of the aggregate. The efficiency of the alternative solution is highlighted by a comparative presentation of the internal forces and deformations recorded in different areas 
of the historic building, first for the singular building and secondly of the building integrated into the new bearing structure. Internal forces and displacements were obtained following a spatial seismic analysis, performed with the ETABS program. In the same time, photographs of the execution, that present the connection between the buildings and the chosen consolidation solutions used to reduce the seismic vulnerability of the building, are presented throughout the paper.

\section{INTRODUCTION}

In general, the load-bearing structure of a historical building is strengthened based on a set of analyses and calculations that are applied only on the studied building, without also considering the load transfer between the buildings of an aggregate. This is difficult to do since execution details and the state of conservation in the contact area of the two buildings are hard to assess. In addition, some owners do not accept on-site investigations. This interaction between the buildings forming an aggregate is highlighted when the analysis performed on an individual building indicates the occurrence of significant damage for a given PGA, but in reality, the historical building is not presenting significant structural damages after several earthquakes.

Of course, an explanation for this can be the mechanical properties used in the numerical simulations, which are strongly reduced according to the standards, certain details which were not included into the simulations or the forces taken into account, higher compared to the real ones. In these cases, the numgrical simulations highight the need for massive, extensive and long-term consolidatio recommendations regar reconstruction of the buildings composing the Generally, for an indi
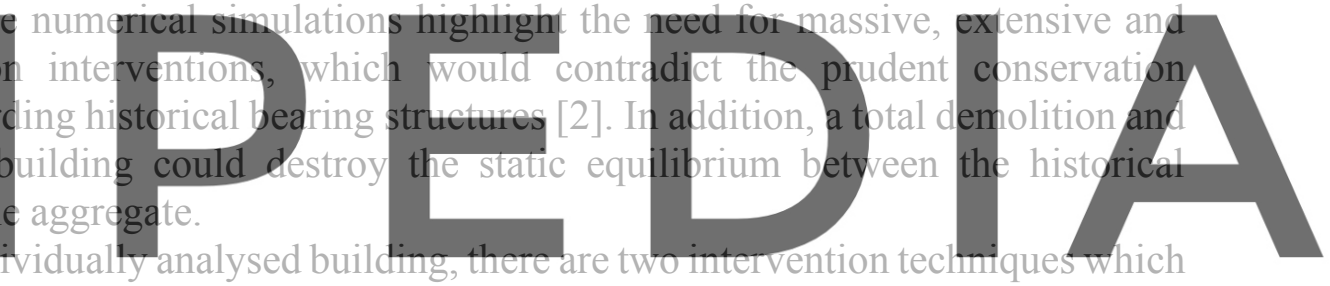

have to be considered: the local consolidation of the load-bearing elements or the preservation

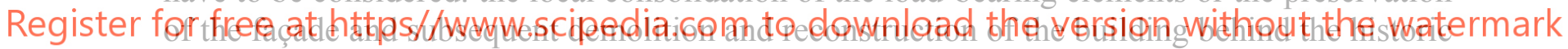

facade. Unfortunately, these solutions cannot be used if the neighbouring buildings have different foundations, are in a bad state of conservation, the walls are presenting significant outof-plane deformation, or the mechanical properties of the materials of the historic building are strongly reduced.

Considering these, the paper is presenting a complex consolidation solution, which maintains a static equilibrium between the neighbouring buildings by saving the facade and a significant area of the historic building.

\section{THE STRUCTURE AND ITS STATE OF CONSERVATION}

The historic buildings are located on 3 different plots (Figure 1) [1]. Located close to the St. George square, two of the buildings (no. 2 and 3), used to have a C-shaped plan while the neighbouring building (St. George square no. 4) is presenting an O-shape with an inner courtyard.

The investor bought the St. George square no. 2 and 3 buildings and leased the St. George square no. 4 one. Following a thorough technical and economic analysis, it turned out that it would be the most efficient to build a hotel on the considered plots [3] (Figure 2). 


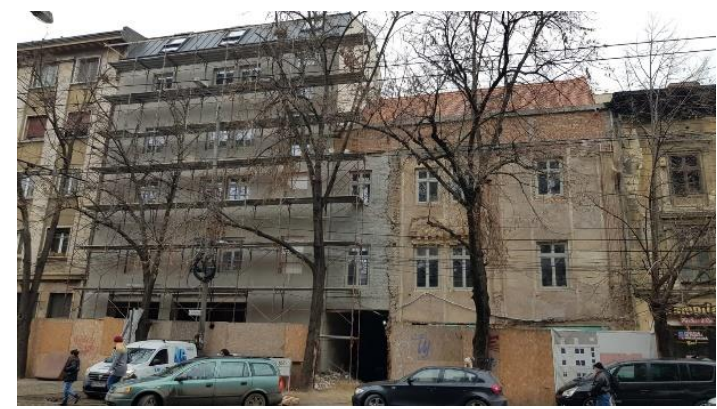

a)

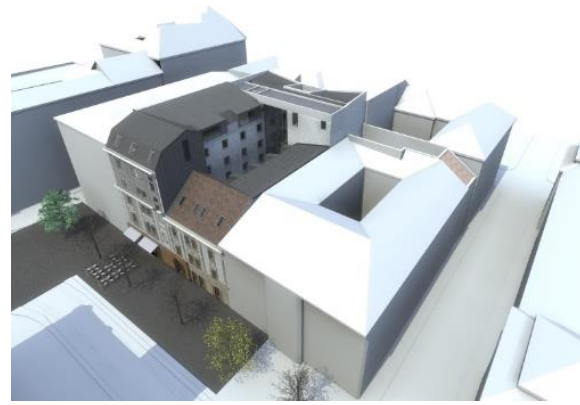

b)

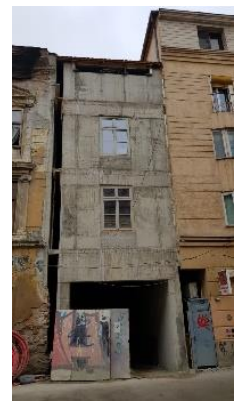

c)

Figure 1: a) St. George square no. 2 and 3 buildings facades; b) proposed building - 3D model; c) St. George square no. 4 building facade
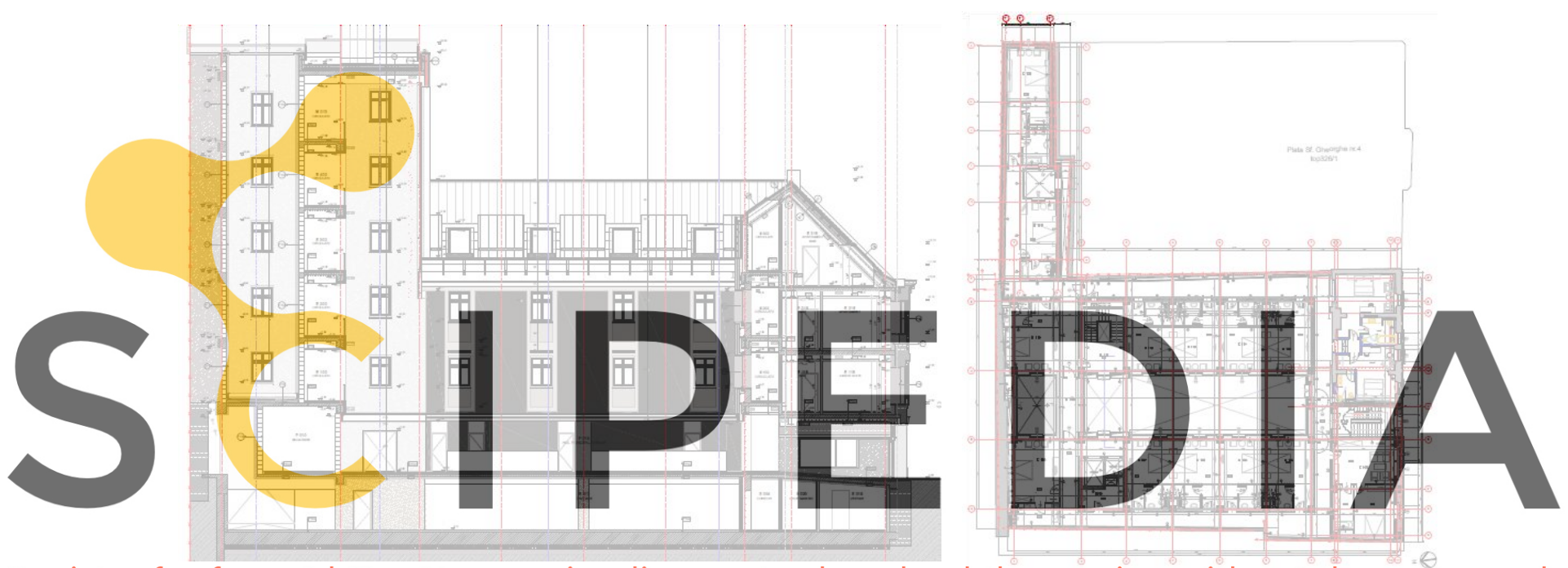

Register fogl free at https//www.scipedia.com to download, the version without the watermark Figure 2: a) Transversal section of the building; b) plan of the proposed building

The buildings are located in an aggregate of historical buildings inside the former fortress area of the city of Timisoara. The buildings were made of brick masonry and lime mortar. The basement and upper floor walls had thicknesses between $75-85 \mathrm{~cm}$ while the façade walls had a thickness of $75 \mathrm{~cm}$ on the ground floor decreasing down to $45 \mathrm{~cm}$ on the second floor. The interior walls had a thickness of $45 \mathrm{~cm}$. The height of the floors is also changing. Therefore, the underground floor had a height of $2.30 \mathrm{~m}$, the ground floor, $3.10 \mathrm{~m}$, and the upper floors 3.47 $\mathrm{m}$, respectively $2.40 \mathrm{~m}$. The underground and ground floor had vaulted brick floors supported by arches. The first and second floor, on the other hand, presented wooden floors without brick arches.

The roof structures, placed on the buildings facing the street were very rigid, being composed of two layers of structural elements in the transversal direction (interior strutting device and exterior rafters connected by a collar beam) and diagonal elements placed between the rafters in the longitudinal direction $[4,5]$. The buildings also had steel straps in the transversal direction connecting the exterior walls. 
The buildings were built during the Habsburg administration, which demolished almost all the buildings of the old city from the Ottoman period. The reuse of the old Ottoman foundations, after 1716, and the weak foundation ground produced numerous structural damages caused mainly by differential settlements. At the same time, the earthquakes recorded in the Banat seismic area are characterized by a PGA of $0.20 \mathrm{~g}$ [6], which is amplifying these damages. However, no historical brick masonry building has suffered failure after an earthquake or after the settlements [7-10]

The onsite assessments carried out for these buildings highlighted that all the buildings of the aggregate were working together in transferring the seismic loads and the settlements and were in a state of equilibrium in 2012, the year the project was started. At that time, significant parts of the St. Gheorghe no. 2 and 3 buildings were in a bad state of conservation and in a precollapse condition, due to poor maintenance. The northern part of the St. Gheorghe no. 4 building suddenly collapsed in July 1988 after wrong construction work was done at a neighbouring building.

Therefore, due to the differential settlements, vertical cracks and significant damages of the walls, the doors and windows sills, arches and brick vaults were visible. Still, there were no cracks or fissures identified which could have been caused earthquakes, although some earthquakes had the epicentre about 10km from Timisoara $[11,12]$.

\section{THE SOLUTION}

\section{Initially, the hotel $w$}

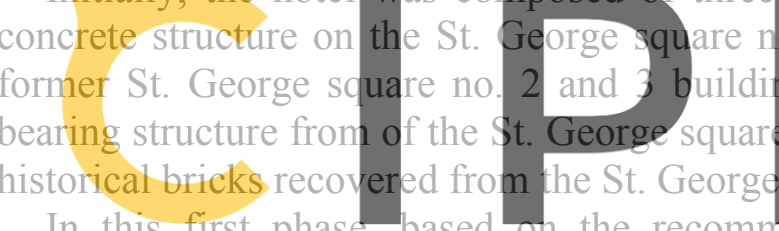

In this first phase,

the recomn
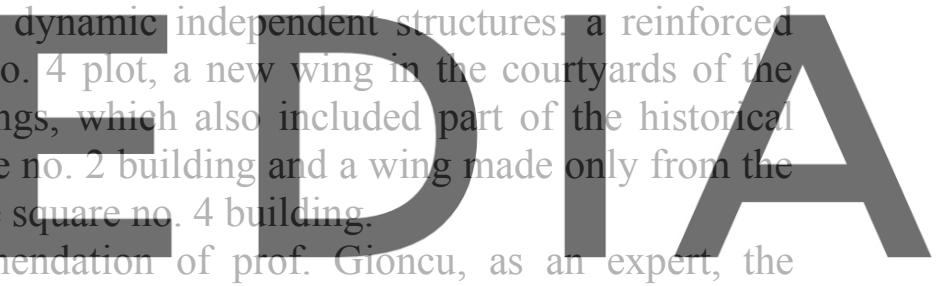

preservation of the entire basement and ground floor of the historic brick masonry load-bearing

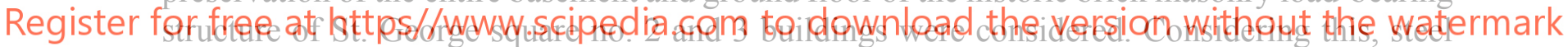

columns had been embedded in the masonry walls of the remaining load-bearing structures,

which were transformed, above the ground-fioor into composite columns. For this purpose, the brick walls from the underground and the ground floor had to be strengthened.

The new construction made in the courtyard of the buildings was designed using reinforced concrete, having a rigid central perforated core, two rigid concrete tubes in the access path area and columns near to the neighbouring buildings. These columns were placed at a minimum distance of 1.50 from the neighbouring buildings, in order not to transmit loads to the foundation ground of these buildings. From the perimeter columns, cantilevers were placed towards the neighbouring buildings and a gap between the old and new of $5 \mathrm{~cm}$ considered [13] (Figure 3).

The load-bearing structure solution was developed after several types of structural systems were analysed. The spatial response of all considered solutions to various loads was studied with the help of the ETABS software. Finally, the most rigid solution, with a perforated inner tube was chosen, because according to the numerical simulations, the risk of collision between the neighbouring buildings and the new building during an earthquake could be avoided.

Ultimately, the historical facade was only preserved for the St. George square no. 3 building. 
For this, the facade was consolidated and supported with a steel structure. Unfortunately, it was not possible to also preserve the façade of the St. George square no. 2 building since according to the project, three additional upper floors were designed over the original two.

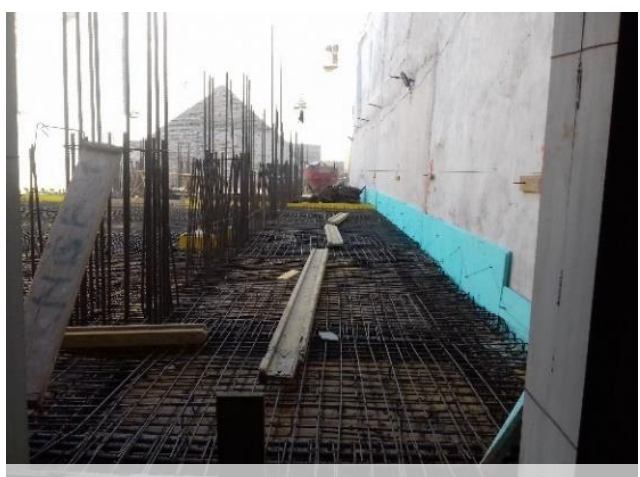

a)

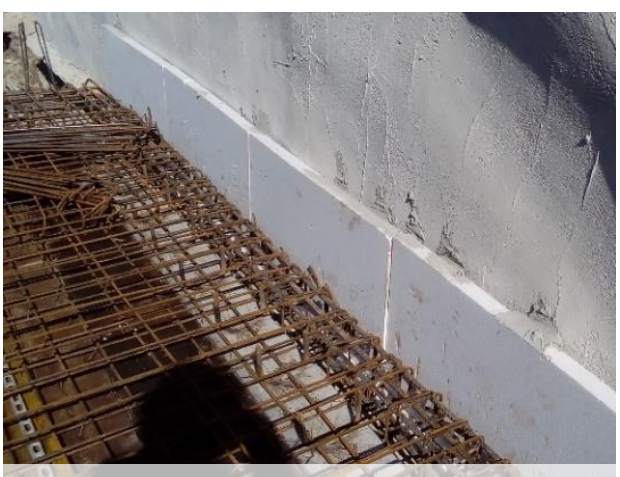
cantilevers and the neighbouring buildings

The load-bearing structure of the St. George square no. 4 building was made out of concrete walls and reinforced concrete slabs (Figure 4a).

Because it was also necessary to include an underground parking lot, in the underground

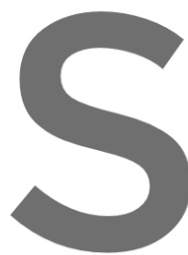
level area outside the $\mathrm{h}$ In order to prevent the it was considered to bui
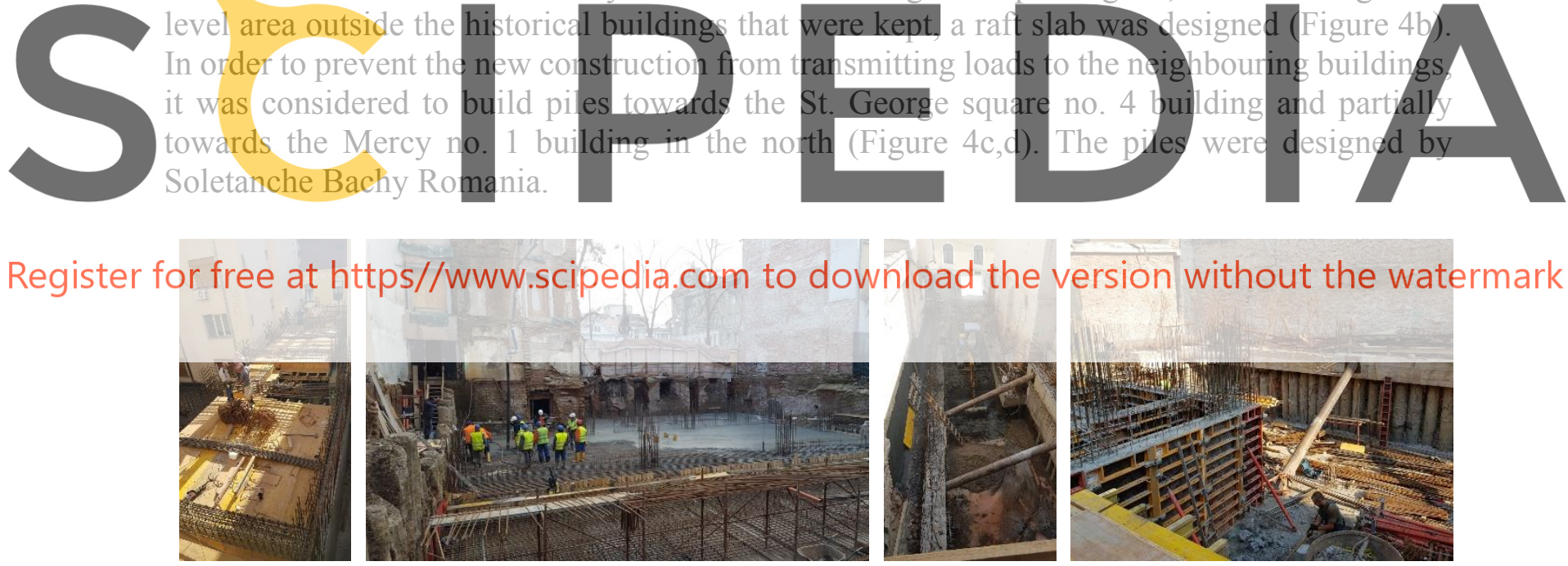

a)
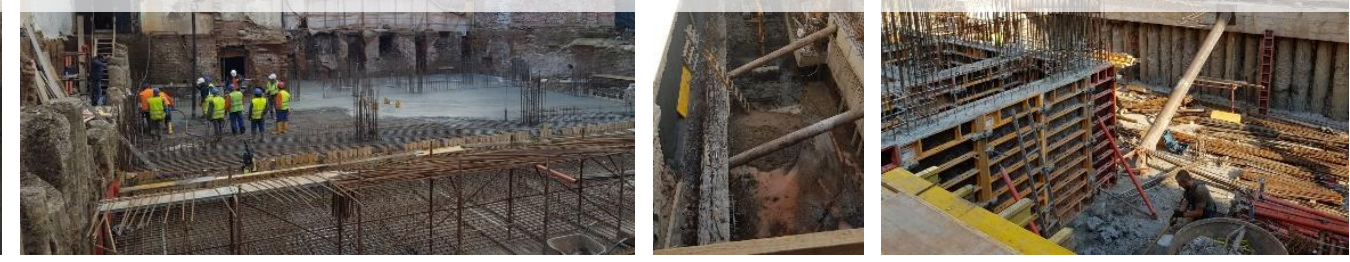

c)

d)

Figure 4: a) Reinforced concrete wall and floor of the new St. George square no. 4 building; b) raft slab in the area outside the St. George square no. 2 and 3 buildings; c) special foundations towards the old St. George square no. 4 building; d) special foundations of the St. George square no. 2 and 3 buildings.

Before the demolition works began, visual inspections were carried out in the neighbouring buildings where the access was allowed. All the cracks in these buildings were photographed, and devices for measuring the cracks were mounted, in order to be able to record their evolution during the construction works.

However, the initial project had to be adapted and modified due to unforeseen situations 
discovered on-site during the works. The modifications made, were meant to ensure the structural safety of the historical buildings on site (St. George square no. 2 and 3) as well as of the neighbouring buildings during the construction works, thus managing to maintain the balance of the entire aggregate of buildings. For each change which was made to the loadbearing structure, a spatial analysis of the buildings was made, thereby verifying the effectiveness of the proposed changes.

The following measures were taken:

1. Four rooms were kept from the St. George square no. 3 historical building in order to take over the loads from the St. George square no. 4 building (Figure 5a).

2. The historical building was connected to the very rigid reinforced concrete structure in the floors area (Figure 5b). This structural solution allowed the reduction of the internal forces and deformations of the historical structure and implicitly the reduction of the expenses.

Figure 5c shows the contact wall between the historic building and the neighbouring building. The wall is delimited at the top by points 1 and 2. The vibration modes and periods of the connected buildings are shown in Figure 6. In figure 7 and in table 1, it can be observed that the inter-story drift values do not exceed the allowed limits. On the last floor, these values increase because this level was designed as future meeting rooms of the hotel and therefore made using a steel structure.

Table 2 presents comparative values of the horizontal out-of-plane and in-plane displacements of the wall in the contact area between the St. George square no. 3 and 4 buildings. The horizontal displacements were calculated for a $q$ factor of 2 , for the new building,

since according to the simulations, the buildings proved out to have a sensibility to torsion and
1.65 for the original historical building. The displacements were deternined in the corner of
the building at the level of each floor, beheath point 1 ( 1 igure $5 \mathrm{c}$ ). It can be observed that out-
of-plane displacements are almost unchanged for the two cases, while the in-plane
displacements are reduced with approximately $50 \%$ in the case of the proposed building.
By increasing the stiffness, consolidating the historic floors and connecting the historic

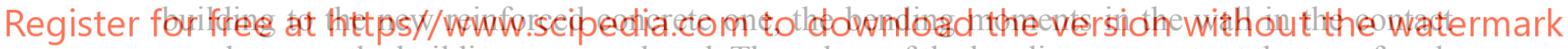
area between the buildings were reduced. The values of the bending moments at the top of each wall at every level, on the corner of the building (Figure 5c - point 1) are presented in table 3.

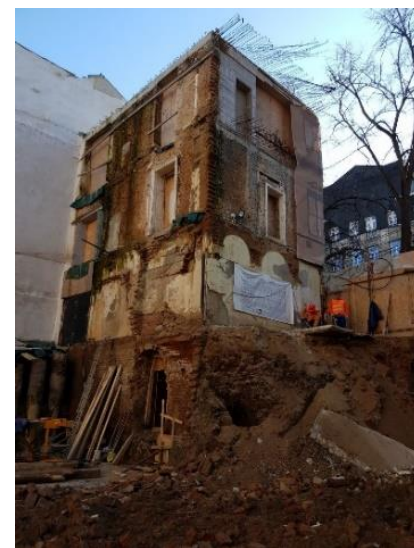

a)

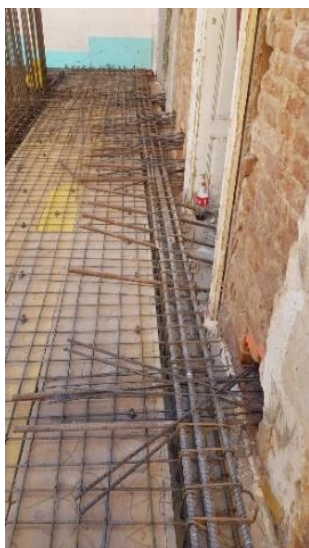

b)

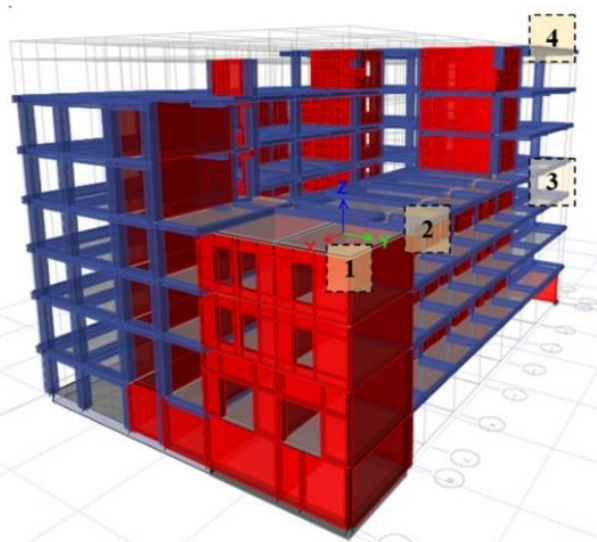

c)

Figure 5: a) Preserved section of the historic masonry building; b) connection between the historic and new building; c) contact area between St. George square no. 3 and 4 


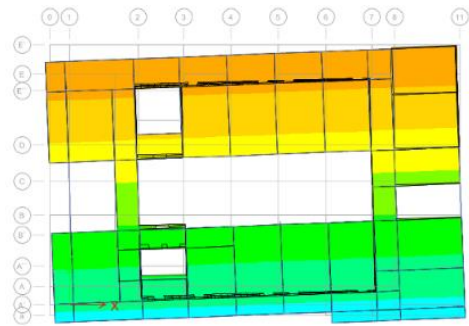

a)

Figure 6: Vibration modes a) Vibration mode $1-\mathrm{T} 1=0.309 \mathrm{sec}$; b) Vibration mode $2-\mathrm{T} 2=0.202 \mathrm{sec}$; )

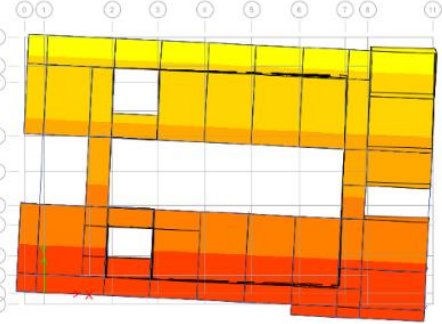

c)
Vibration mode $3-\mathrm{T} 3=0.159 \mathrm{sec}$

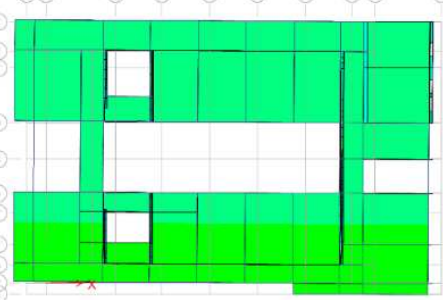

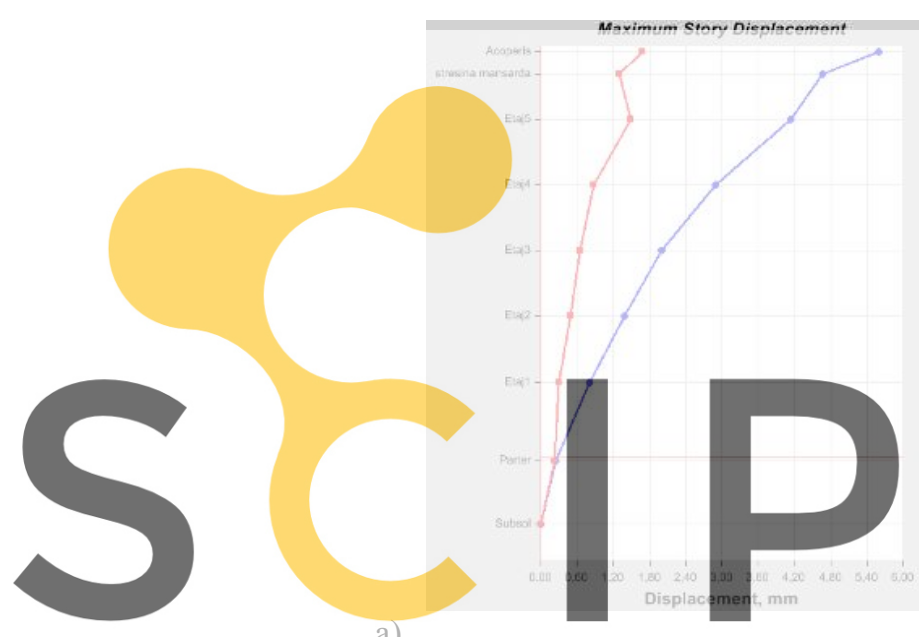

a)
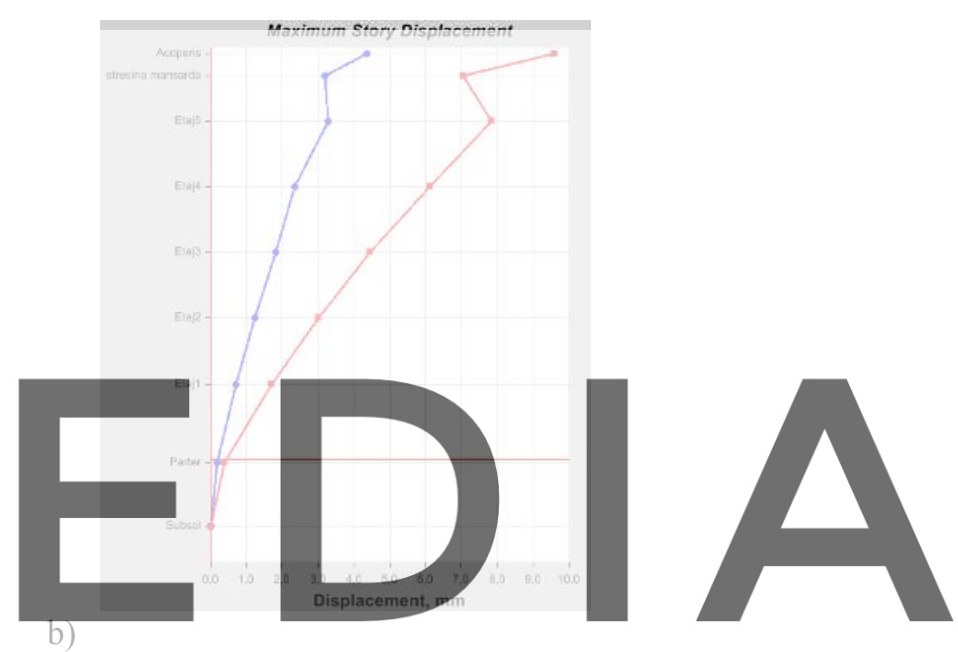

Figure 7: Inter-story drift

Register for free at https//www.scipedia.com to download the version without the watermark

Table 1: In-plane and out-of-plane inter-story drift ratio (in point 1)

\begin{tabular}{ccc} 
Level & \multicolumn{2}{c}{ Story drift } \\
\hline $\mathrm{m}$ & OX\%o & OY\%o \\
\hline 3.60 & 0.147 & 0.347 \\
\hline 7.30 & 0.182 & 0.413 \\
\hline 10.05 & 0.193 & 0.444 \\
\hline 13.25 & 0.360 & 0.527 \\
\hline 16.45 & 0.393 & 0.533 \\
\hline 18.65 & 0.471 & 0.177 \\
\hline 19.75 & 0.419 & 0.513
\end{tabular}

Table 2: In-plane and out-of-plane displacement (in point 1) 


\begin{tabular}{ccccc}
\multicolumn{2}{c}{ Level } & Out-of-plane horizontal displacement $[\mathrm{mm}]$ & In-plane horizontal displacement $[\mathrm{mm}]$ \\
\hline $\mathrm{m}$ & before & after & before & after \\
\hline 3.60 & 1.71 & 2 & 4.64 & 2.38 \\
\hline 7.30 & 3.18 & 3.28 & 8.12 & 3.54 \\
\hline 10.05 & 4.43 & 4.68 & 10.18 & 4.64
\end{tabular}

Table 3: Bending moments before and after consolidation interventions (in point 1)

\begin{tabular}{ccc} 
Level & \multicolumn{2}{c}{ Bending moment $[\mathrm{kNm}]$} \\
\hline $\mathrm{m}$ & before & after \\
\hline 0 & 39 & 16 \\
\hline 3.60 & 53 & 20 \\
\hline 7.30 & 14 & 8 \\
\hline 10.05 & 0 & -4.60
\end{tabular}

\section{A raft slab was made in the underground of all the buildings. This foundation solution} reduced the values of the internal forces and the settlements of the foundations. In the contact area between the hotel's foundation and the St. George square no. 4 historical building, the maximum vertical deformation according to the numerical simulations is rather small, of 4.60 mm (Figure 8).
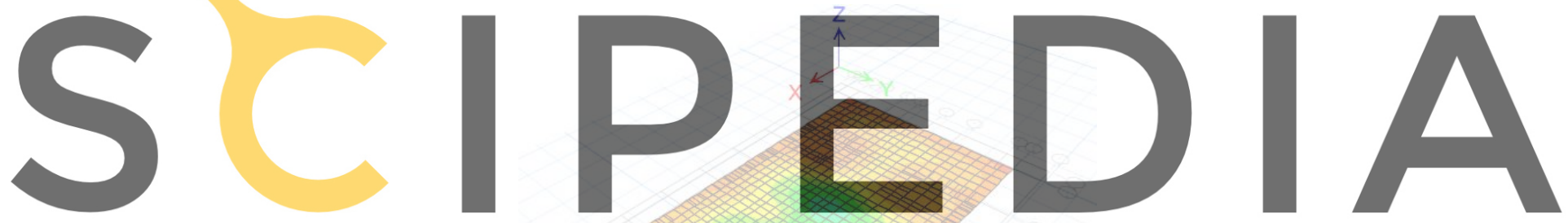

Register for free at https//www.scipedia.com to download the version without the watermark

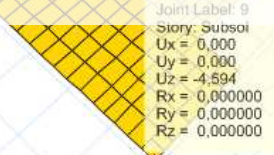

Figure 8: Deformation of the raft slab

4. The original wall was kept the entire length of the St. George square no. 4 building. This wall was reinforced with FRP and is in contact with the reinforced concrete beams from the new building (Figure 9). On the upper floors, between the beams and the walls of the neighbouring buildings, a $5 \mathrm{~cm}$ gap was left. In this way, in the case of an earthquake, the new building could take over but not transmit the seismic loads to the St. George square no. 4 building. 


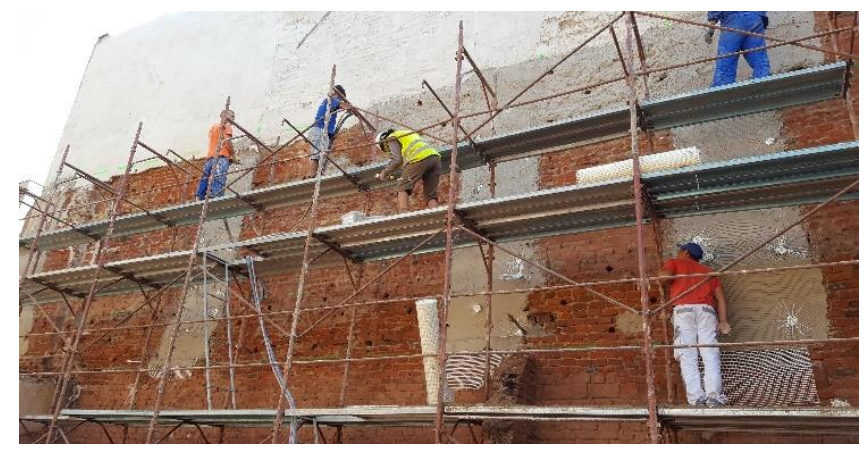

Figure 9: Consolidation of the St. George square no. 4 building wall which was not demolished using Kerakoll products

5. In order to prevent the earth discharge from beneath the foundations of the St. George square no. 4 building, reinforced concrete support walls were made, along its entire length (Figure 10).
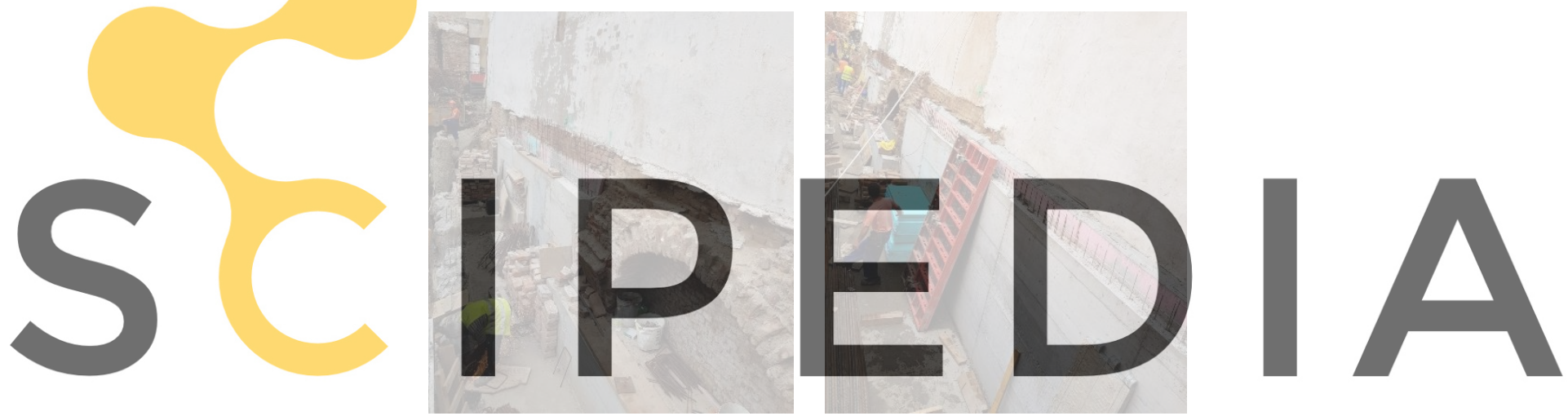

Register forfree at https//WWW.Scipedia.com to download the version without the watermark

6. Due to the significant damage caused by settlements, the underground floor area of the St.

George square no. 2 building was demolished. The vaults were rebuilt with the original bricks (Figure 11).

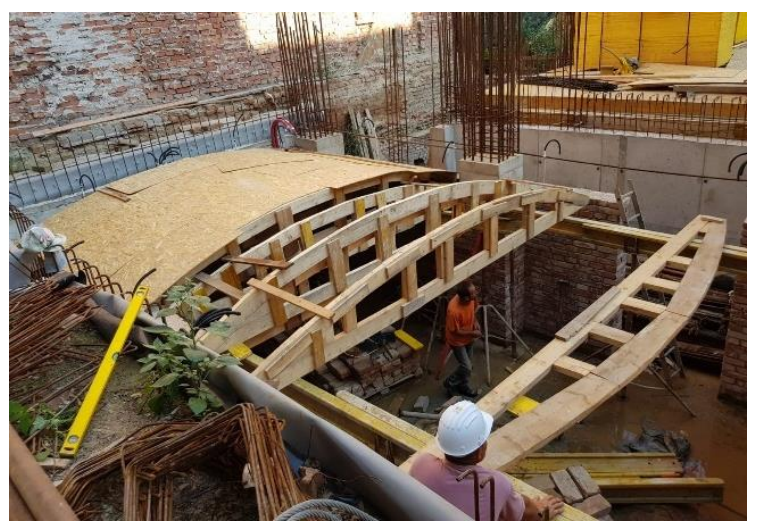

Figure 11: Reconstruction of the underground floor vaults of the St. George square no. 2 building 


\section{CONCLUSIONS}

The paper presents an intervention method which allows the construction of a new building in an aggregate of historical buildings in Timisoara. The proposed solution did not produce damage to the neighbouring buildings, allowed the preservation of a larger area of the historical buildings, reduced the execution time and the volume of material that had to be disposed of during the demolitions, without affecting the safety of the neighbouring buildings during the works and after their completion. This was made possible by efficiently combining the advantages offered separately by each structure, being a project in which the new and the old combine perfectly.

\section{REFERENCES}

[1] Mosoarca, M., Stoian, V., Florea, M. and Niculescu, M. Structural Balance of Historical Aggregates. In: Aguilar R (eds.). Structural Analysis of Historical Constructions, SAHC2018.Springer, Cham, Cusco, Peru, (2018), pp. 2448-2456.

[2] ICOMOS. International Charter for the Conservation and Restoration of Monuments and Sites (The Venice Charter 1964). Venice, Italy, (1964) https://www.icomos.org/charters/venice_e.pdf (accessed 5 May 2017).

[3] S.C. D Proiect S.R.L. Architectural design project no. 61/2012. (2012).

[4] Keller, A., Chieffo, N. and Mosoarca, M. Influence of roof structures on seismic behavior of historic buildings. In: Mazzolani F (eds.). 3rd International Conference on Protection

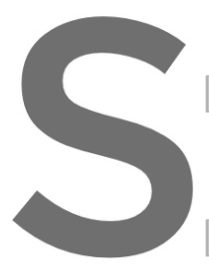
Of Historical Const
Keller, A., Paris
structures on the
(2019): $1-27$
MDRAP. Romanian
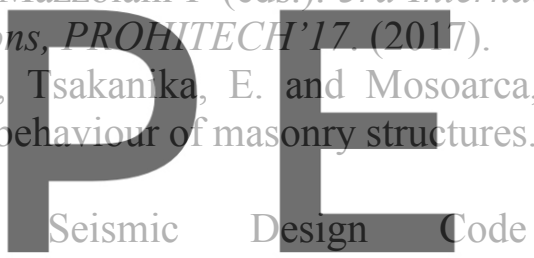
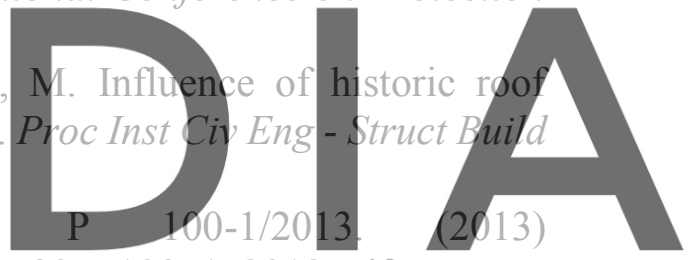

http://www.mdrap.ro/userfiles/reglementari/Domeniul_I/I_22_P100_1_2013.pdf

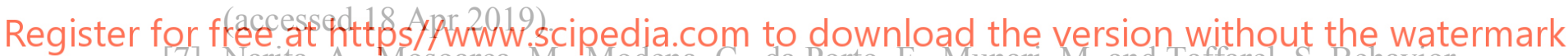
Narita, A., Mosoarca, M., Modena, C., da Porto, F., Munari, M. and Taffarel, S. Behavior of Historic Buildings in Zones with Moderate Seismic Activity. Case Study: Banat Region,

Romania. Procedia Eng (2016) 161:729-737.

[8] Taffarel, S. Marson, C. Valotto, C. Roverato, M. Munari, M. da Porto, F., Modena, C. and Mosoarca, M. Seismic vulnerability maps of Timisoara historical center based on fragility curves. In: Van Balen K (eds.). 10th International Conference on Structural Analysis of Historical Constructions, SAHC 2016.CRC Press, Taylor \& Francis Group, Leuven, Belgium, (2016), pp. 1605-1612.

[9] Chieffo, N., Mosoarca, M., Formisano, A. and Apostol, I. Seismic Vulnerability Assessment and Loss Estimation of an Urban District of Timisoara. IOP Conf Ser Mater Sci Eng (2019) 471(6).

[10] Apostol, I., Mosoarca, M., Chieffo, N. and Onescu, E. Seismic vulnerability scenarios for Timisoara, Romania. In: Aguilar R., Torrealva D., Moreira S., Pando M.A. RLF (eds.). Structural Analysis of Historical Constructions. Springer International Publishing, Cham, (2019), pp. 1191-1200.

[11] Oros, E. Earthquakes in the Banat plain (in Romanian). Graffiti, Timisoara, Romania, (1991) doi:10.13140/2.1.2740.5126. 
[12] Oros, E. and Diaconescu, M. Recent vs. historical seismicity analysis for Banat seismic region (western part of Romania). In: Vacareanu R (eds.). Proceedings of the 5th National Conference on Earthquake Engineering and 1st National Conference on Earthquake Engineering and Seismology. CONSPRESS, (2014) doi:10.13140/2.1.3497.7601.

[13] SC H.I. Struct. Structural design project - St George square buildings. (2012). 